\title{
MODEL SYSTEMS DYNAMICS UNTUK MEMINIMALKAN PENYIMPANGAN BIAYA MATERIAL PROYEK KONSTRUKSI INDUSTRI
}

\author{
Davied Insja ${ }^{1}$, Sofia W. Alisjahbana ${ }^{2}$ dan Onnyxiforus Gondokusumo ${ }^{3}$ \\ ${ }^{1}$ Mahasiswa Doktor Ilmu Teknik Sipil, Program PascaSarjana, Universitas Tarumanagara, Jakarta \\ idavied@yahoo.co.id \\ ${ }^{2}$ Guru Besar, Program Pascasarjana, Universitas Tarumanagara, Jakarta. \\ ${ }^{3}$ Dosen, Program Pascasarjana, Universitas Tarumanagara, Jakarta. \\ onnyxiforusg@pps.untar.ac.id
}

\begin{abstract}
ABSTRAK
Penyimpangan biaya adalah fenomena yang sangat sering terjadi dan terkait dengan hampir semua proyek dalam industri konstruksi. Kecenderungan ini semakin meningkat pada proyek-proyek konstruksi yang terletak di daerah dengan aksesibilitas yang relatif sulit. Dalam rangka untuk mencegah dan mengurangi penyimpangan biaya, penelitian ini bertujuan untuk mengidentifikasi faktor-faktor dominan yang mempengaruhi penyimpangan biaya dan termasuk tindakan perbaikan, tindakan pencegahan atau mitigasi penyimpangan biaya pada proyek konstruksi industri. Kuesioner survei dibagikan kepada para profesional dan data dianalisis melalui metode statistik. Dari 74 faktor yang diidentifikasi melalui studi literatur kemudian diklasifikasikan menjadi 13 peristiwa risiko dan 61 sumber risiko. Dengan memanfaatkan metode Delphi dan analisis faktor akhirnya diperoleh 9 peristiwa risiko dan 25 sumber risiko. Selanjutnya, melalui evaluasi risiko, diperoleh rekomendasi untuk pencegahan dan mitigasi dampak dari penyimpangan biaya material dalam proyek konstruksi. Tindakan pencegahan dan mitigasi diperlukan untuk mengurangi penyimpangan biaya. Namun, pada saat yang sama, diperlukan biaya untuk menjalankan tindakan pencegahan dan mitigasi itu sendiri. Sehubungan dengan itu, untuk mengetahui lebih lanjut tentang biaya aktual akhir, digunakan metode simulasi seperti metoda system dynamics dengan pendekatan kuantitatif dalam bentuk implementasi alokasi biaya dan sumberdaya.Pemilihan metode system dynamics juga disebabkan oleh faktor risiko yang saling berinteraksi satu sama lain dan berubah-ubah menurut waktu tertentu. Hasil dari simulasi model system dynamics menunjukkan bahwa biaya penyimpangan material dapat dikurangi apabila dilakukan intervensi.
\end{abstract}

Kata kunci: cost overrun, proyek konstruksi industri, peristiwa risiko, sumber risiko.

\section{PENDAHULUAN}

Dalam setiap proyek konstruksi, selalu dihadapkan pada berbagai potensi risiko yang disebabkan oleh ketidak-pastian. Semakin besar skala, kompleksitas dan kesulitan lokasi proyek, semakin besar pula tingkat dan jumlah risiko yang akan dihadapi. Dengan kata lain, Risiko mempunyai dampak yang signifikan terhadap kinerja dari proyek konstruksi (Wideman, 1992).

Perubahan biaya proyek atau peningkatan biaya sebagai hasil dari berbagai faktor yang membentuk dampak risiko yang saling berhubungan, menyebabkan 86 persen proyek infrastruktur berskala besar dari berbagai negara mengalami rata-rata penyimpangan biaya (cost overrun) sebesar 28 persen (Flyvbjerg, 2003). Hal yang sama diungkapkan oleh Love et al. (2011) bahwa penyimpangan biaya proyek infrastruktur yang terjadi di Australia rata-rata sebesar 13,55 persen. Pada bagian lain Jackson (2002), mengemukakan bahwa 55 persen dari proyek konstruksi di Inggris mengalami penyimpangan biaya, diantaranya ada yang mencapai 30 persen, bahkan ada yang lebih dari 100 persen.

Penyimpangan biaya terjadi, terutama disebabkan oleh tidak adanya standar atau peraturan perhitungan yang berlaku (Boukendour, 2005). Menurut Wan (2014), metode-metode analisis risiko yang ada pada saat ini, pada dasarnya merupakan metode probalistis, sehingga tidak dapat menggambarkan sejumlah fenomena dinamika yang melekat pada setiap proyek konstruksi. Faktanya adalah, pada proyek konstruksi tidak hanya tentang berapa jumlah dan besaran faktor risiko, tetapi juga interaksi satu sama lain disebabkan oleh kondisi rekayasa yang kompleks dari proyek konstruksi. Hal ini terjadi karena metode ini tidak mempunyai kemampuan untuk meng- 
kuantifikasi dampak secara penuh dari risiko yang berbeda sebagaimana halnya tidak dapat mempertimbangkan akibat tidak langsung dari risiko. Selanjutnya, Nasirzadeh (2008), mengusulkan pendekatan system dynamics perlu dipertimbangkan mengingat sifat dasar dinamis risiko dari seluruh siklus hidup proyek, sama halnya dengan memperhatikan simpal arus balik (feedback loops) yang mempengaruhi semua dampak dari risiko. Mengenai model untuk proyek manajemen, menurut Sterman (1992), proyek-proyek skala besar merupakan system dynamics yang kompleks karena proyek yang sangat kompleks itu terdiri dari beberapa komponen yang saling bergantung; sangat dinamis; melibatkan beberapa proses umpan balik; melibatkan hubungan nonlinear; melibatkan kedua perangkat data yang keras dan lunak. Untuk mengelola kompleksitas seperti ini, sebuah model harus mampu mewakili sistem dengan karakteristik seperti yang disebutkan sebelumnya dan harus dipahami dan digunakan oleh manajer proyek.

Penelitian ini bertujuan untuk membuat model system dynamics sebagai salah satu metoda untuk menentukan penyimpangan biaya material proyek bangunan konstruksi industri. Dalam hal ini, pemodelan system dynamics ini merupakan tahap akhir dari semua rangkaian penelitian. Adapun tahap penelitian sebelumnya, sudah pernah dipresentasikan di konferensi ilmiah dan di anataranya sedang dalam proses pengajuan untuk publikasi ilmiah. Penelitian dilaksanakan dengan terbatas pada penyimpangan biaya material pada proyek bangunan konstruksi industri yang berada di lokasi dengan aksesibilitas relatif sulit, yaitu lokasi dengan kondisi material jauh dari sentra produksi, struktur/alinyemen jalan yang labil, lalu lintas yang padat, moda transportasi yang berubah serta hambatan lain yang menimbulkan biaya tinggi.

\section{METODE PENELITIAN}

Metode penelitian dilakukan dengan beberapa tahap, sebagai berikut:

\section{Tahap I}

Pada tahap ini, dilakukan studi literatur untuk memperoleh variabel-variabel faktor risiko yang berdampak terhadap risiko penyimpangan biaya pada proyek bangunan industri. Faktor risiko tersebut diklasifikan menjadi sumber risiko dan peristiwa risiko. Data ini, kemudian dikonfirmasikan dalam bentuk kuesioner kepada para pakar dengan metode Delphi.

\section{Tahap II}

Hasil konfirmasi dari para pakar ini, kemudian menjadi acuan dalam membuat instrumen kuesioner yang akan disebarkan kepada praktisi proyek. Kusioner ini dibuat untuk mengetahui faktor risiko yang berpengaruh terhadap penyimpangan biaya material dan frekuensi terjadinya sumber risiko, format kuesioner bagian pertama seperti pada Tabel 1 berikut:

Tabel 1: Kuesioner praktisi proyek

\begin{tabular}{|c|c|c|c|c|c|c|c|c|c|c|c|}
\hline \multirow[t]{2}{*}{ No } & \multirow[t]{2}{*}{ Sumber Risiko } & \multicolumn{4}{|c|}{$\begin{array}{c}\text { Tingkat pengaruh } \\
\text { terhadap } \\
\text { penyimpangan } \\
\text { biaya material }\end{array}$} & \multicolumn{5}{|c|}{$\begin{array}{c}\text { Frekuensi yang } \\
\text { terjadi }\end{array}$} & \multirow[t]{2}{*}{$\begin{array}{c}\text { Tindakan } \\
\text { preventif, korektif } \\
\text { dan mitigasi }\end{array}$} \\
\hline & & 12 & 3 & 4 & 5 & 1 & 2 & 3 & 4 & 5 & \\
\hline \multicolumn{12}{|c|}{ Ekonomi } \\
\hline 1 & Inflasi & & & & & & & & & & \\
\hline 2 & Fluktuasi nilai tukar & & & & & & & & & & \\
\hline
\end{tabular}


Keterangan:

Tingkat pengaruh:
$1=$ Tidak berpengaruh $($ Penyimpangan biaya material $=0 \%$ )
$2=$ Kurang $($ Penyimpangan biaya material, $0-10 \%)$
$3=$ Sedang $($ Penyimpangan biaya material, $10-20 \%)$
$4=$ Besar $($ Penyimpangan biaya material, $20-30 \%)$
$5=$ Sangat besar $($ Penyimpangan biaya material $>30 \%)$

$$
\begin{aligned}
& \text { Frekuensi: } \\
& 1=\text { Tidak Pernah } \\
& 2=\text { Jarang } \\
& 3=\text { Kadang-kadang } \\
& 4=\text { Sering } \\
& 5=\text { Selalu }
\end{aligned}
$$

\section{Tahap III}

Variabel-variabel yang telah dikumpulkan, kemudian dianalisis dengan dengan menggunakan analisis faktor, sehingga diperoleh peristiwa dan sumber risiko yang paling dominan terhadap penyimpangan biaya material.

\section{Tahap IV}

Mengevaluasi dan membuat rekomendasi dalam mencegah dan mengurangi penyimpangan biaya material pada proyek konstruksi industri dengan pendekatan kualitatif dan kuantitatif berdasarkan respons yang diperoleh tentang tindakan preventif dan mitigasi.

\section{Tahap V}

Evaluasi dengan pendekatan kuantitatif yang diimplementasikan dalam alokasi biaya dan sumber daya dijadikan sebagai dasar dalam pembentukan system thingking yang kemudian menjadi model kualitatif system dynamics (mental model).

\section{Tahap VI}

Model kualitatif system dynamics (mental model) dijabarkan ke dalam bentuk model kuantitatif system dynamics dengan menggunakan perangkat lunak Powesim versi 10.

\section{HASIL DAN PEMBAHASAN}

\section{Survei Responden}

Pada penelitian ini survei dilakukan menjadi dua tahap, yaitu survei responden dengan penyebaran kuisioner kepada responden ahli, serta penyebaran kuisioner kepada responden praktisi.

\section{Survei Tahap Pertama Responden Pakar}

Jumlah responden pakar yang didapat adalah sebanyak 9 responden yang terdiri dari pakar konstruksi, dengan latar belakang pendidikan S1 sebanyak $67 \%$ dan S2 sebanyak $33 \%$. Adapun pengalaman pakar di dunia konstruksi, seperti pada Tabel 2 berikut:

Tabel 2. Latar Belakang Pengalaman Pakar

\begin{tabular}{cccc}
\hline No & Pengalaman Pakar (Tahun) & Jumlah & Persentase (\%) \\
\hline 1 & $15-25$ & 6 & 67 \\
\hline 2 & $26-35$ & 3 & 33 \\
\hline
\end{tabular}




\section{Survei Tahap Kedua Responden Praktisi}

Jumlah responden praktisi yang didapat adalah sebanyak 30 responden, dengan latar belakang pendidikan D3 sebanyak $6.6 \%$, S1 sebanyak $66.7 \%$, dan S2 sebanyak $26.7 \%$. Adapun pengalaman pakar di dunia konstruksi, seperti pada Tabel 3 berikut:

Tabel 3. Latar Belakang Pengalaman Praktisi

\begin{tabular}{cccccccc}
\hline No & $\begin{array}{c}\text { Pengalaman } \\
\text { Praktisi (Tahun) }\end{array}$ & Jumlah & $\begin{array}{c}\text { Persentase } \\
\text { (\%) }\end{array}$ & No & $\begin{array}{c}\text { Pengalaman } \\
\text { Praktisi (Tahun) }\end{array}$ & Jumlah & $\begin{array}{c}\text { Persentase } \\
\text { (\%) }\end{array}$ \\
\hline 1 & $5-10$ & 16 & 53.3 & 3 & $16-20$ & 4 & 13.3 \\
\hline 2 & $11-15$ & 7 & 23.4 & 4 & $21-25$ & 3 & 10 \\
\hline
\end{tabular}

Faktor risiko yang paling berpengaruh terhadap penyimpangan biaya material.

Faktor-faktor yang dominan terhadap penyimpangan biaya diperoleh setelah dilakukan tiga tahap penelitian. Pada tahap I, dari studi kepustakaan yang dilakukan diperoleh sejumlah 74 faktor risiko, selanjutnya diklasifikasikan menjadi 13 peristiwa dan 61 sumber risiko. Pada tahap II, dilakukan verifikasi oleh para pakar serta berdasarkan tambahan dari peneliti, maka didapatkan 10 peristiwa dan 37 sumber risiko. Selanjutnya pada tahap III dilakukan analisis faktor terhadap hasil kuesioner praktisi, sehingga faktor risiko direduksi menjadi 9 peristiwa dan 25 sumber risiko. Selanjutnya 25 sumber risiko ini akan dimasukkan sebagai variabel input model system dynamics. Sehingga data flow untuk sumber dan peristiwa risiko dapat dilihat pada Gambar 1 .

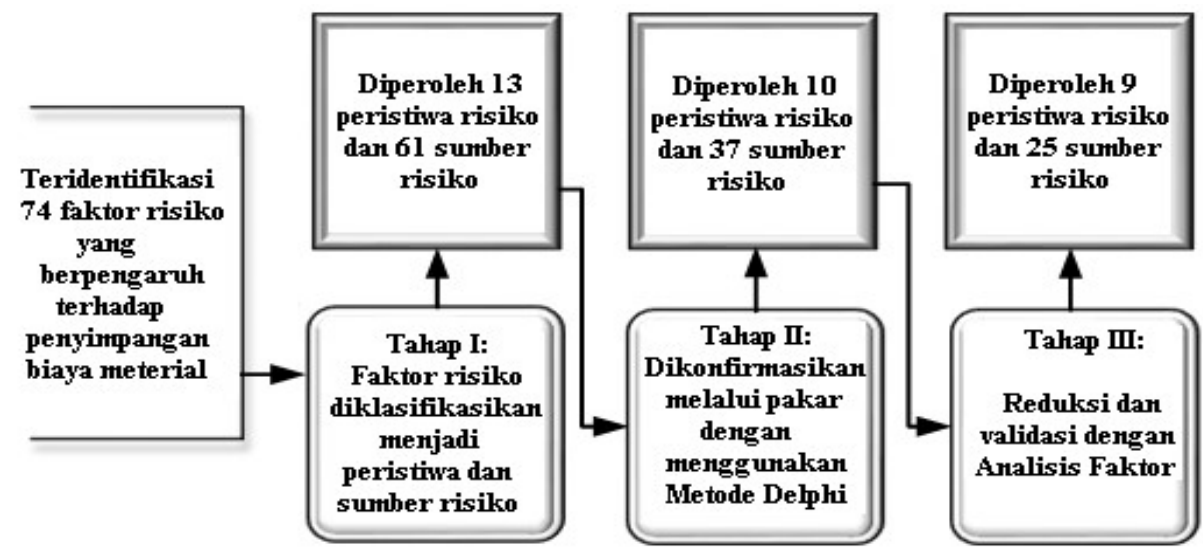

Gambar 1. Data flow untuk sumber dan peristiwa risiko

Adapun 9 peristiwa risiko yang paling berpengaruh terhadap penyimpangan biaya material adalah seperti pada Tabel 4 berikut:

Tabel 4. Peristiwa Risiko yang Paling Berpengaruh Terhadap Penyimpangan Biaya Material

\begin{tabular}{llll}
\hline No & Peristiwa risiko & No & Peristiwa risiko \\
\hline 1 & X1 = Fluktuasi harga material & 6 & X7 = Kerusakan material \\
2 & X3 = Biaya distribusi material di lingkungan site & 7 & X8 = Pekerjaan ulang \\
3 & X4 = Biaya keterlambatan material & 8 & X9 = Kehilangan material \\
4 & X5 $=$ Biaya perubahan spesifikasi dan tipe material & 9 & X10 = Kualitas material yang berlebihan \\
5 & X6 = Kekurangan jumlah material & & \\
\hline
\end{tabular}




\section{Rekomendasi Tindakan Preventif dan Mitigasi terhadap Penyimpangan Biaya Material.}

Seperti yang ditunjukkan pada Tabel 1, terdapat pertanyaan tindakan preventif, korektif dan mitigasi terhadap sumber dan peristiwa risiko. Sehingga diharapkan dapat meminimalisasi penyimpangan biaya material. Tindakan preventif, korektif dan mitigasi dikatagorikan menjadi pendekatan kuantitatif dan kualitatif seperti pada Tabel 5 berikut:

Tabel 5. Tindakan Preventif, Korektif dan Mitigasi

\begin{tabular}{|c|c|c|}
\hline \multirow{2}{*}{ Source of Risk } & \multicolumn{2}{|c|}{ Tindakan Preventif, Korektif dan Mitigasi } \\
\hline & Kualitatif & Kuantitatif \\
\hline \multicolumn{3}{|l|}{ I. Fluktuasi Harga Material } \\
\hline \multirow[t]{3}{*}{$\begin{array}{ll}\text { - } & \text { Inflasi } \\
\text { - } & \text { Fluktuasi nilai tukar } \\
\text { - } & \text { Resesi ekonomi }\end{array}$} & $\begin{array}{l}\text { Membuat rata-rata kenaikan harga dari tahun } \\
\text { lalu sehingga didapat perkiraan kenaikan harga }\end{array}$ & $\begin{array}{l}\text { Menambahkan biaya sebagai } \\
\text { langkah antisipasi untuk mengatasi } \\
\text { inflasi dan fluktuasi nilai tukar }\end{array}$ \\
\hline & Fixed price pada kontrak pembelian & \\
\hline & $\begin{array}{l}\text { Fluktuasi material masuk sebagai harga } \\
\text { penawaran proyek }\end{array}$ & \\
\hline \multicolumn{3}{|c|}{ II. Biaya distribusi material di lingkungan site } \\
\hline \multirow{3}{*}{$\begin{array}{l}\text { Kondisi tanah site } \\
\text { menghambat distribusi } \\
\text { material } \\
\text { - } \\
\text { Keterlambatan penyediaan } \\
\text { pelayanan utilitas } \\
\text { Perencanaan jalan kerja } \\
\text { kurang memadai }\end{array}$} & $\begin{array}{l}\text { Membuat Jadwal kerja mengacu kepada } \\
\text { weather forcast }\end{array}$ & $\begin{array}{l}\text { Pembuatan jalan kerja yang } \\
\text { memadai }\end{array}$ \\
\hline & Menyiapkan infrastruktur yang memadai & Pemeliharaan jalan kerja \\
\hline & $\begin{array}{l}\text { Menyiapkan metode konstruksi jalan kerja yang } \\
\text { efektif }\end{array}$ & Petugas pemelihataan jalan kerja \\
\hline \multicolumn{3}{|c|}{ III. Biaya keterlambatan material (Pengiriman/pengadaan) } \\
\hline \multirow{4}{*}{$\begin{array}{ll}- & \text { Ketergantungan kepada } \\
\text { pemasok tertentu } \\
\text { Kurangnya perencanaan \& } \\
\text { manajemen material }\end{array}$} & $\begin{array}{l}\text { Menyiapkan vendor cadangan sebagai } \\
\text { pengganti jika timbul masalah pada vendor awal }\end{array}$ & Buffer stock \\
\hline & $\begin{array}{l}\text { Perencanaan pembelian dan strategi pembelian } \\
\text { material yang baik }\end{array}$ & $\begin{array}{l}\text { Menambah supervisor dan personil } \\
\text { logistik }\end{array}$ \\
\hline & $\begin{array}{l}\text { Perencanaan dan penjadwalan pengiriman yang } \\
\text { efisien \& efektif }\end{array}$ & Memperluas Stock-pile \\
\hline & $\begin{array}{l}\text { Monitoring dan pengawasan pembelian dan } \\
\text { pengiriman secara terus menerus }\end{array}$ & \\
\hline \multicolumn{3}{|c|}{ IV. Biaya perubahan spesifikasi dan tipe material } \\
\hline \multirow{5}{*}{$\begin{array}{ll}\text { - } & \text { Perubahan lingkup } \\
\text { - } & \text { Perubahan desain dan } \\
\text { rekayasa } \\
\text { - Spesifikasi dan tipe } \\
\text { material langka. }\end{array}$} & Desain Awal yang lebih baik & $\begin{array}{l}\text { Design Engineer \& Material } \\
\text { Engineer yang Qualified }\end{array}$ \\
\hline & Design awal FEED perlu simulasi yang teliti & $\begin{array}{l}\text { Menambahkan anggaran biaya } \\
\text { sebagai langkah antisipasi untuk } \\
\text { mengatasi perubahan lingkup, } \\
\text { perubahan desain serta rekayasa } \\
\text { dan spesifikasi dan tipe material } \\
\text { langkah }\end{array}$ \\
\hline & $\begin{array}{l}\text { Melaksanakan tahapan proyek (Basic Design } \\
\text { dan EPC) }\end{array}$ & \\
\hline & $\begin{array}{l}\text { Perubahan lingkup \& Disain di antisipasi } \\
\text { dengan pasal di dalam kontrak. }\end{array}$ & \\
\hline & $\begin{array}{l}\text { Klarifikasi gambar kerja yang detail saat } \\
\text { aanwyzing }\end{array}$ & \\
\hline
\end{tabular}


V. Kekurangan jumlah material

- Desain tidak lengkap Perlunya perencanaan yang lebih matang dan

- Perhitungan jumlah material yang tidak akurat

- Pemakaian material kurang efisien

info data yang akurat harus dimiliki oleh designer

Kesalahan engineering dikurangi dengan monitoring dari fase FEED oleh engineering berpengalaman, sehingga dapat mencegah kesalahan di procurement $\&$ construction

Perencanaan dan pengawasan proses pengadaan dan pengiriman material yang konfrehensif

Kontrol logistik di site dibuat teliti

\section{Kerusakan Material}

- Kerusakan material karena kondisi penyimpanan yang tidak baik

- Kerusakan material pada saat pengiriman
Perencanaan dan pengawasan penyimpanan material yang lebih baik

Menyimpan material dengan baik dan tempat yang memadai
Procurement harus merencanakan dengan
Menambah supervisor.

matang untuk rencana kedatangan material

berdasarkan rencana kerja yang telah dibuat,

kondisi alam termasuk hujan, jalan menuju ke

lokasi.

Membuat prosedur bongkar muat barang

Pemilihan metode angkutan dan vendor

angkutan yang benar

\section{Pekerjaan Ulang}

- Perubahan akibat kesalahan Membuat perencanaan design yang baik desain

- Kesalahan dalam metode kerja

- Kualitas dan kemampuan kerja kurang baik

Pemahaman terhadap situasi kerja perlu dimatangkan karena berbeda lokasi maka berbeda pula proses/metode kerja di lapangan

Perencanaan pekerjaan, metode kerja dan pengawasan yang lebih baik

Menggunakan gambar kerja yang terakhir

disetujui

Membuat prosedur kerja untuk setiap kegiatan

konstruksi termasuk prosedur Keselamatan

Kerja

\section{Kehilangan Material}

- Pencurian material

- Prosedur pengecekan keluar masuk material kurang
Pengadaan Design's Engineer \& site's estimator.

Memperhitungkan penambahan biaya kekurangan material.

Memperhitungkan Packing

Material

Mengadakan asuransi.
Engineer \& tenaga kerja yang berkompetensi tinggi Memperkirakan fraksi penambahan material
Penyimpanan material yang tertutup

Format-format standar penyerahan material wajib dilakukan

Membuat prosedur keluar masuk barang

Stok opname yang rutin disesuaikan dengan

progress pekerjaan

\section{Kualitas material yang berlebihan}

- Kurangnya perencanaan \& manajemen material

- Kesalahan dalam pembelian

- Tidak akurat dalam membaca spesifikasi

- Pengetahuan tentang kualitas material yang kurang
Perencanaan dan manajemen material yang lebih baik

Pemeriksaan spesifikasi material dengan rutin sebelum di buat PO

Membuat spesifikasi material yang jelas dalam $\mathrm{PO} /$ Kontrak

Kontrak dipahami secara utuh
Menambah petugas keamanan Memperkuat gudang penyimpanan material. 
Pendekatan kuantitatif dari alokasi risiko telah dikembangkan untuk mengatasi keterbatasan pendekatan kualitatif, terutama berapa banyak risiko yang harus ditanggung oleh masing-masing pihak dan diimplementasikan dalam bentuk alokasi biaya dan sumber daya.

\section{Pemodelan system dynamics penyimpangan biaya material.}

Pemodelan system dynamics penyimpangan biaya material proyek konstruksi industri, dimulai setelah diperoleh faktor dominan yang mempengaruhi penyimpangan biaya beserta tindakan preventif dan mitigasi. Sebelum itu, terlebih dahulu dibuat model kualitatif (mental model) sebagai pedoman dalam pembentukan model system dynamics. Untuk menggambarkan hubungan dari variabel variabel tersebut, dapat dilihat pada Gambar 2.

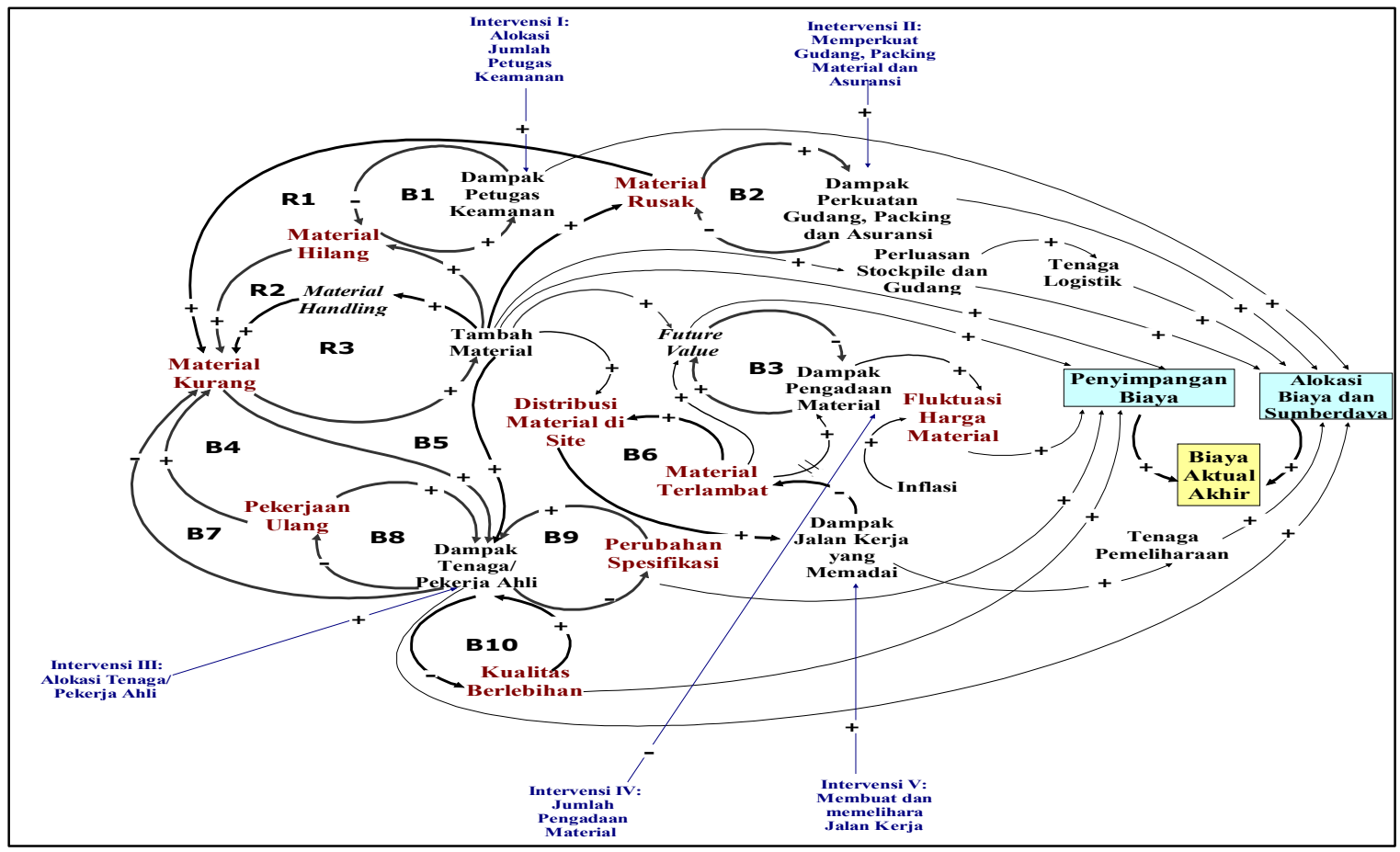

Gambar 2. Model kualitatif (mental model) system dynamics

Pada model kualitatif ini, terlihat penanganan risiko dalam bentuk alokasi biaya dan sumber daya sebagai intervensi untuk mengurangi biaya penyimpangan material, seperti alokasi jumlah tenaga keamanan, tenaga ahli, perkuatan gudang, asuransi, pembuatan jalan kerja yang memadai, perkiraan jumlah pengadaan material dan sebagainya. Terlihat juga, sebagai konsekuensi dari penanganan risiko, menimbulkan biaya penyelenggaraan intervensi. Pada sisi lain, peristiwa risiko dalam model kualitatif ini saling berhubungan satu sama lain, seperti material yang rusak, material yang hilang, pekerjaan ulang menimbulkan kekurangan material. Akibat dari kekurangan material, menyebabkan penambahan material dan semakin banyak penambahan material semakin besar pula potensi dari kehilangan dan kerusakan material. Pada saat yang sama, penambahan material juga mengakibatkan distribusi material semakin besar dan cenderung menyebabkan keterlambatan material demikian juga terjadi peristiwa lainnya. Mental model ini, selanjutnya dikembangkan menjadi model kuantitatif system dynamics seperti pada Gambar 3. 


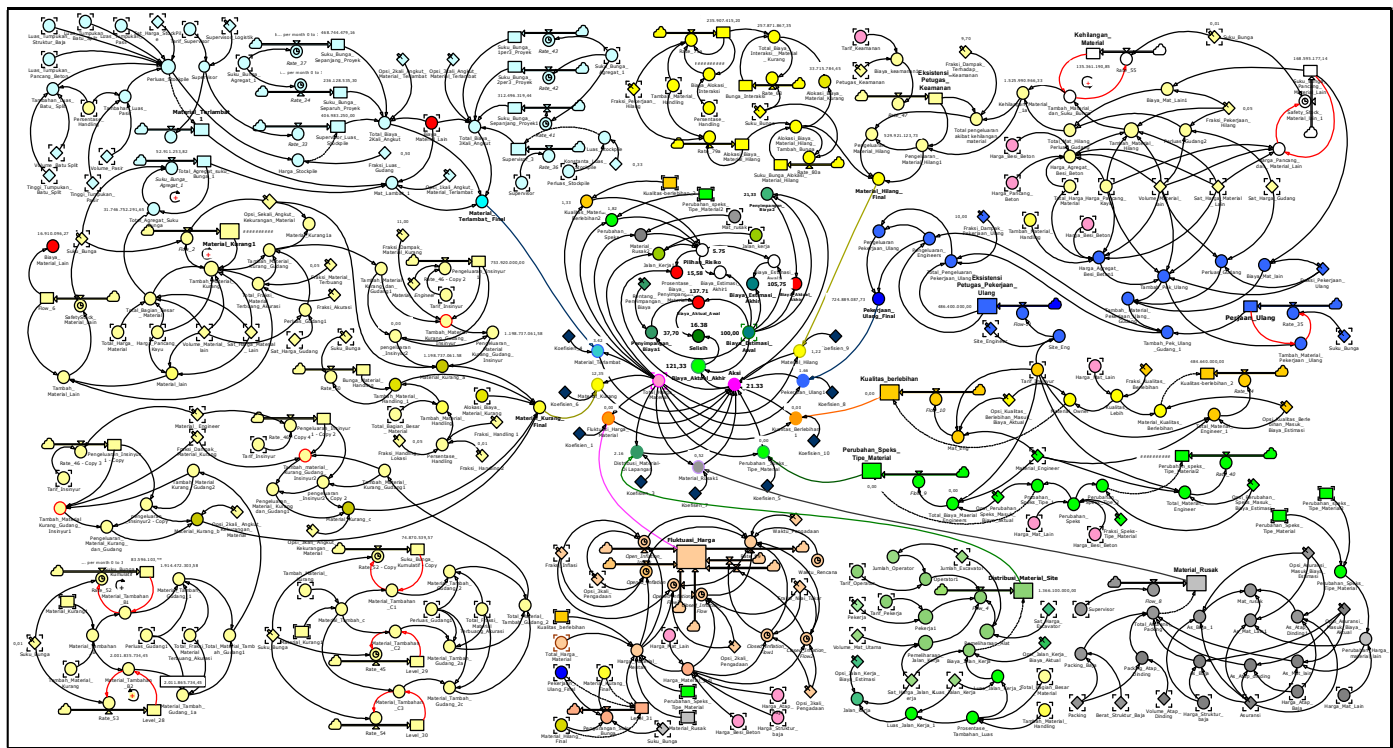

Gambar 3. Model kuantitatif system dynamics

Dalam model kuantitatif, beberapa contoh sub-model resiko penyimpangan biaya proyek konstruksi, seperti pada Gambar 4 dan Gambar 5 berikut:

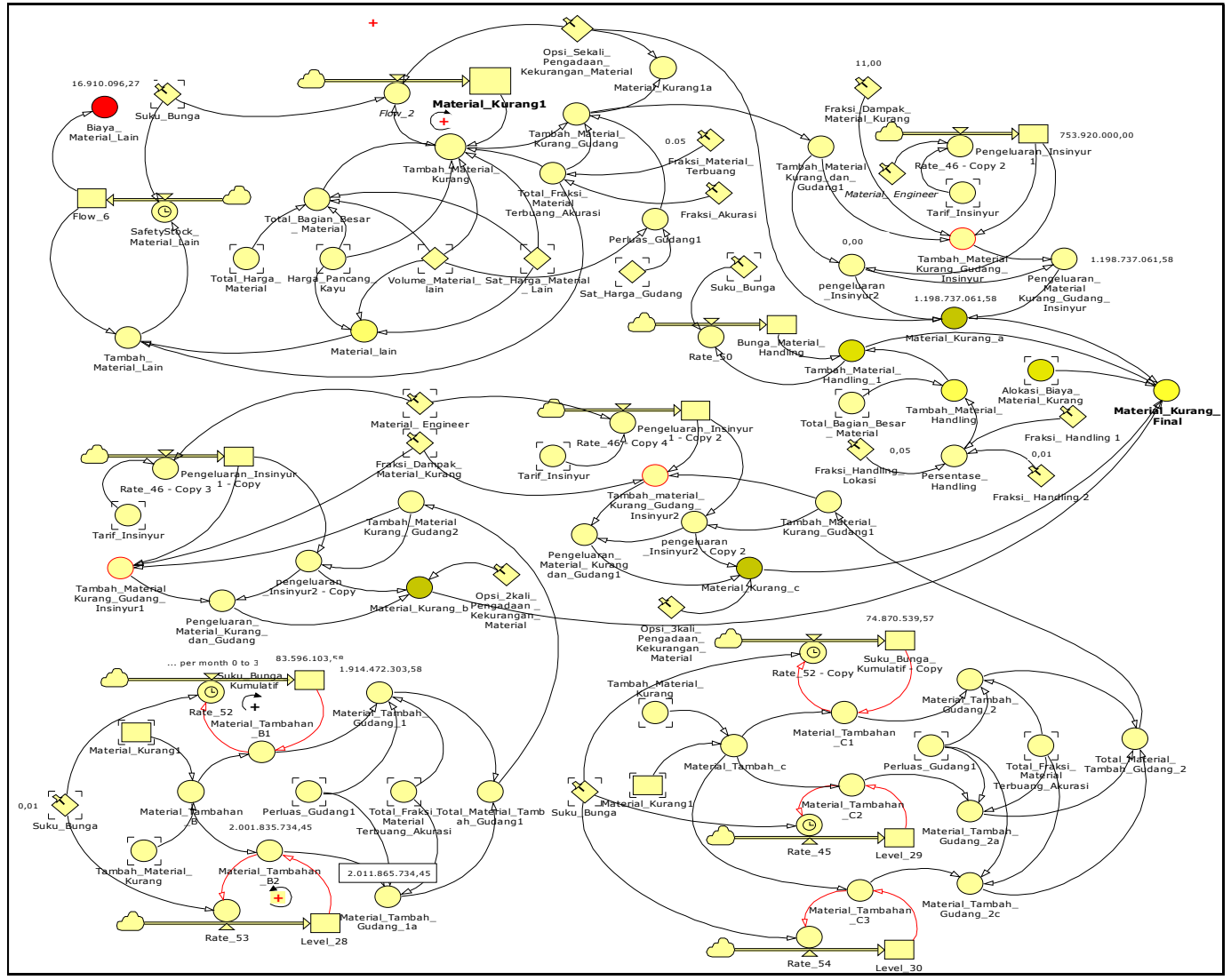

Gambar 4. Sub-model 5: kekurangan jumlah material 


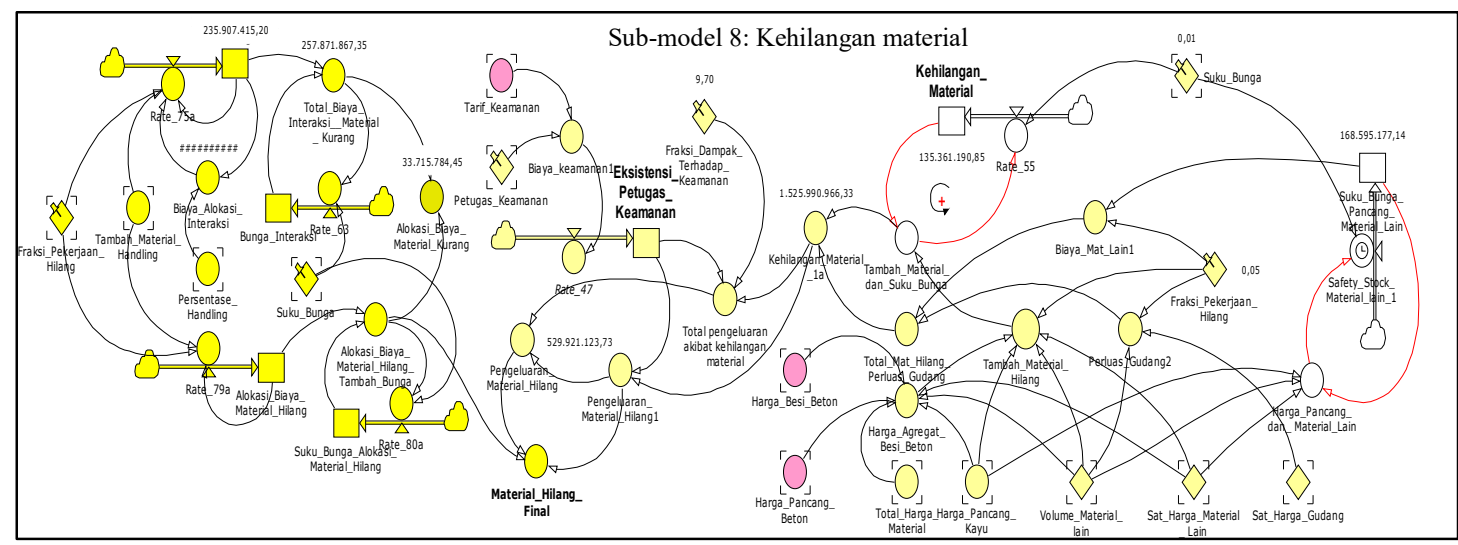

Gambar 5. Sub-model 8: kehilangan material

\section{Simulasi model system dynamics penyimpangan biaya material}

Rangkaian hasil simulasi dari masing-masing variabel akan membentuk hasil akhir sebagai biaya yang diperlukan untuk mengantisipasi penyimpangan biaya material. Hasil simulasi ini, mengindikasikan bahwa penyimpangan biaya dapat dikurangi, apabila dikelola dengan baik dan diantisipasi dengan melakukan tindakan preventif sebelum pelaksanaan proyek.

Hasil simulasi selama kurun waktu 19 bulan dapat juga dilihat pada tabel waktu yang disediakan pada papan slider (Gambar 6). Pada bagian ini, memperlihatkan biaya aktual awal sebesar 137,71 persen; biaya aktual akhir sebesar 121,33 persen; biaya estimasi awal (base line) sebesar 100 persen; biaya estimasi akhir sebesar 105,75 persen. Demikian pula, diperlihatkan biaya penyimpangan material sebesar 15,58 persen.

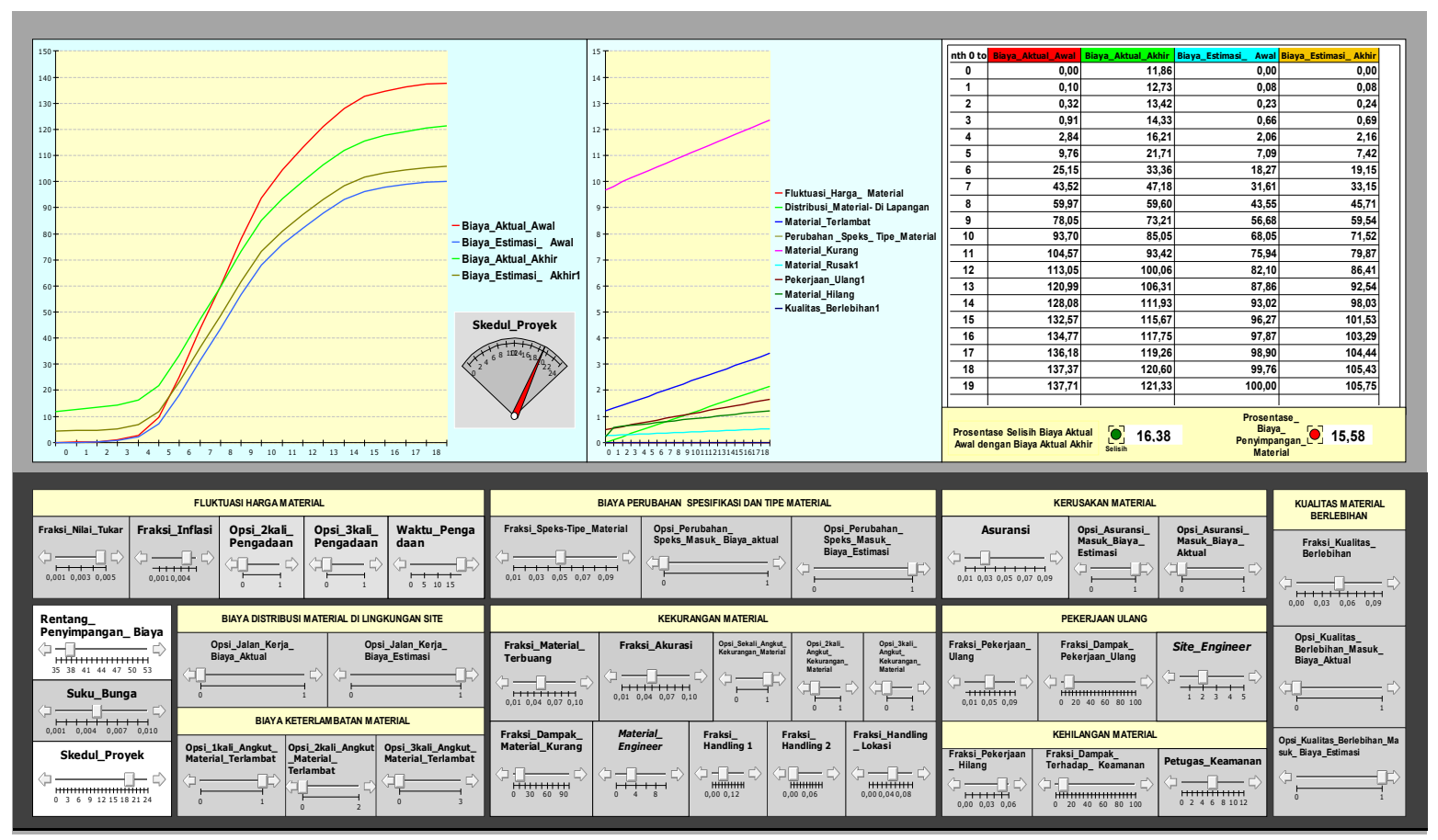

Gambar 6. Papan Slider untuk Simulasi Model System Dynamics 


\section{KESIMPULAN}

Berdasarkan hasil analisis dan pembahasan yang telah dilakukan pada bab sebelumnya, maka dapat ditarik kesimpulan sebagai berikut:

1. Model system dynamics pada penelitian ini, dapat dijadikan sebagai salah satu metode untuk menentukan besaran penyimpangan biaya material proyek konstruksi industri, disebabkan oleh: Fleksibilitas dalam meng-input data ril yang mencerminkan kondisi proyek yang sebenarnya. Memberi peluang untuk menentukan pilihan dalam tindakan preventif dan mitigasi terhadap risiko penyimpangan biaya material yang sesuai dengan kondisi proyek yang sedang dihadapi. Melalui proses umpan balik, peristiwa-peristiwa risiko dapat saling berinteraksi satu sama lain dalam model ini. Dalam model aplikatif ini, terdapat "papan slider", untuk mempermudah proses dan presentasi simulasi model system dynamics.

2. Hasil dari simulasi model system dynamics menunjukkan bahwa biaya penyimpangan material dapat dikurangi apabila dilakukan intervensi dengan tindakan preventif dan mitigasi, meskipun terdapat biaya dalam mengadakan intervensi. Selanjutnya penyimpangan biaya material akan semakin meningkat dan berbanding positif dengan keterlambatan proyek dari durasi yang sudah direncanakan sebelumnya. Hal ini disebabkan oleh suku bunga dan site's overhead yang terus berlangsung selama proyek berjalan.

\section{Ucapan Terima Kasih (Acknowledgement)}

Penulis menyampaikan ucapan terima kasih kepada Prof. Dr. Agustinus Purna Irawan, S.T., M.T., selaku Rektor Universitas Tarumanagara, dan kepada seluruh Civitas Akademica Universitas Tarumanagara.

\section{REFERENSI}

Boukendour, S. (2005).“A new approach of projects cost overrun and contingency management”. OCRI Parthership Conferences Series Process and Project Management, Ottawa, 22 March 2005.

Flyvbjerg, B., Holm, S., \& Bohl (2003). How common and how large are cost overruns in transport infrastructure project ?. Transport Reviews, 23(1), 71-88.

Jackson, S. (2002). Project cost overruns and risk management, School of Construction Management and Engineering, The University of Reading, Berkshire.

Love, PED., Edwards, D., \& Irani, Z. (2011). Moving beyond optimism bias and strategic misrepresentation: an explanation for social infrastructure project cost overruns. IEEE Transactions Engineering Management, 59(4), 560-571.

Nasirzadeh, F., Afshar, A., \& Khanzadi, M. (2008). System dynamics approach for construction risk analysis. International Journal of Civil Engineering, 6(2), 120-131.

Sterman, JD. (1992). System dynamics modeling for project management. Massachusetts Institute of Technology Cambridge, Massachusetts.

Wideman. RM. (1992). Project and program risk management, a guide to managing project risks and opportunities. The PMBOK Handbook Series - Vol.6, PMI.

Wan, J., \& Liu, Y. (2014). A system dynamics model for risk analysis during construction process. Open Jurnal of Sciences, 2, 451-454. 